\title{
ARTICLE OPEN Significant ground-level ozone attributed to lightning-induced nitrogen oxides during summertime over the Mountain West States
}

\author{
Daiwen Kang (D) ${ }^{1 *}$, Rohit Mathur (D) ${ }^{1}$, George A. Pouliot ${ }^{1}$, Robert C. Gilliam (iD) and David C. Wong (iD)
}

\begin{abstract}
Using lightning flash data from the National Lightning Detection Network with an updated lightning nitrogen oxides $\left(\mathrm{NO}_{\mathrm{x}}\right)$ emission estimation algorithm in the Community Multiscale Air Quality (CMAQ) model, we estimate the hourly variations in lightning $\mathrm{NO}_{x}$ emissions for the summer of 2011 and simulate its impact on distributions of tropospheric ozone $\left(\mathrm{O}_{3}\right)$ across the continental United States. We find that typical summer-time lightning activity across the U.S. Mountain West States (MWS) injects $\mathrm{NO}_{\mathrm{x}}$ emissions comparable to those from anthropogenic sources into the troposphere over the region. Comparison of two model simulation cases with and without lightning $\mathrm{NO}_{x}$ emissions show that significant amount of ground-level $\mathrm{O}_{3}$ in the $\mathrm{MWS}_{\text {during }}$ the summer can be attributed to the lightning $\mathrm{NO}_{x}$ emissions. The simulated surface-level $\mathrm{O}_{3}$ from a model configuration incorporating lightning $\mathrm{NO}_{\mathrm{x}}$ emissions showed better agreement with the observed values than the model configuration without lightning $\mathrm{NO}_{\mathrm{x}}$ emissions. The time periods of significant reduction in bias in simulated $\mathrm{O}_{3}$ between these two cases strongly correlate with the time periods when lightning activity occurred in the region. The inclusion of lightning $\mathrm{NO}_{\mathrm{x}}$ increased daily maximum $8 \mathrm{~h} \mathrm{O}_{3}$ by up to $17 \mathrm{ppb}$ and improved model performance relative to measured surface $\mathrm{O}_{3}$ mixing ratios in the MWS region. Analysis of model results in conjunction with lidar measurements at Boulder, Colorado during July 2014 corroborated similar impacts of lightning $\mathrm{NO}_{x}$ emissions on $\mathrm{O}_{3}$ air quality. The magnitude of lightning $\mathrm{NO}_{x}$ emissions estimated for other summers is comparable to the 2011 estimates suggesting that summertime surface-level $\mathrm{O}_{3}$ levels in the MWS region could be significantly influenced by lightning $\mathrm{NO}_{\mathrm{x}}$.
\end{abstract}

npj Climate and Atmospheric Science (2020)3:6; https://doi.org/10.1038/s41612-020-0108-2

\section{INTRODUCTION}

Due to its adverse impact on human health ${ }^{1}$ and ecosystem well being, ${ }^{2}$ tropospheric ozone $\left(\mathrm{O}_{3}\right)$ has been at the center of air quality research during the past decades. ${ }^{3-5}$ Ground-level $\mathrm{O}_{3}$ is either produced through complex photochemical reactions involving nitrogen oxides $\left(\mathrm{NO}_{\mathrm{x}}\right)$ and volatile organic compounds (VOCs) ${ }^{6}$ with both anthropogenic and natural origins, or transported from other locations. ${ }^{7}$ As air quality regulations are tightened and the contribution of anthropogenic sources to tropospheric $\mathrm{O}_{3}$ levels is reduced in US and other economicallydeveloped regions, the natural sources becomes more increasingly important..$^{8-12}$

Lightning generates relatively large but uncertain quantities of $\mathrm{NO}_{\mathrm{x}}$ and thus strongly impacts the composition of trace gases in the troposphere. ${ }^{13-15}$ Globally, lightning is estimated to generate $2-8 \mathrm{Tg} \mathrm{N}$ per year ${ }^{16}$ which is considerably smaller than presentday global contributions from anthropogenic ( $20.5 \mathrm{Tg} \mathrm{N}$ per year) and biomass burning ( $5.5 \mathrm{Tg} \mathrm{N}$ per year) sources. ${ }^{17}$ Despite the strong influence on troposphere burdens of $\mathrm{O}_{3}$ and $\mathrm{OH}$, impacts of lightning $\mathrm{NO}_{\mathrm{x}}$ emissions on the surface-level air composition and chemistry have been suggested by past studies to be generally small, and thus except for some applications with global models, regional air quality assessments have historically not included lightning $\mathrm{NO}_{\mathrm{x}}$ emissions. ${ }^{16}$ Uncertainties in lightning $\mathrm{NO}_{\mathrm{x}}$ emissions are influenced by limitations in the description of space and time variability in lightning frequency and intensity, $\mathrm{NO}_{\mathrm{x}}$ production rates from lightning flashes, and the vertical distribution and transport of lightning $\mathrm{NO}_{x}$ after its production. Since lightning activity is often associated with deep convection in the atmosphere, the lightning flash rate can be parameterized using convection schemes. ${ }^{18,19}$ However, convection schemes in meteorological models generally show low skill in producing the convective precipitation and the lightning distribution. ${ }^{20,21}$ Though many studies report enhancement in surface-level $\mathrm{NO}_{x}$ levels following thunderstorm activity, the impacts on surfacelevel $\mathrm{O}_{3}$ are ambiguous and typically complicated by the local photochemical conditions such as the availability of other precursors and sunlight. ${ }^{22-25}$ Regional modeling calculations have shown up to $10 \mathrm{ppb}$ enhancements in simulated instantaneous $\mathrm{O}_{3}$ mixing ratios $8,13,23,25$ due to addition of lightning $\mathrm{NO}_{\mathrm{x}}$.

Heath et al. $^{26}$ demonstrated that assimilation of high-quality lightning data from the national lightning detection network (NLDN) in the weather research and forecast (WRF) model considerably improved the simulation of summertime convective activity and rainfall over the continental United States. In this study, we build upon this prior work ${ }^{26,27}$ by implementing lightning $\mathrm{NO}_{x}$ production in the Community Multiscale Air Quality $(\mathrm{CMAQ})^{28-31}$ model based on the NLDN lightning flash data ${ }^{32,33}$ and perform CMAQ simulations driven by the lightningassimilated WRF outputs with (hereafter denoted NLDN) and without (denoted Base) the NLDN-lightning $\mathrm{NO}_{\mathrm{x}}$ production.

\section{RESULTS}

The model performance for $\mathrm{O}_{3}$ predictions, in terms of a particular implementation of lightning $\mathrm{NO}_{\mathrm{x}}$ production, depends on correct $\mathrm{NO}_{x}$ emissions from other sources in the Base model. Uncertainties in specification of precise activity patterns of mobile and

\footnotetext{
${ }^{1}$ Center for Environmental Measurement and Modeling, U.S. Environmental Protection Agency, Research Triangle Park, NC, USA. *email: kang.daiwen@epa.gov
} 
industrial sources lead to uncertainties in space and time variability in estimated emissions from these sources that then translate to biases and errors in model predicted $\mathrm{O}_{3}$ mixing ratios. The addition of lightning $\mathrm{NO}_{\mathrm{x}}$ emissions can then result in further deterioration of model performance for predicted $\mathrm{O}_{3}$ at many locations such as in the eastern U.S. as illustrated in Fig. 1a, which presents the change in bias in simulated surface daily maximum $8 \mathrm{~h}$ (DM8HR) $\mathrm{O}_{3}$ between the NLDN and Base simulations. However, significant impact of lightning $\mathrm{NO}_{x}$ emissions on improving skill of model predictions of surface $\mathrm{O}_{3}$ in the Mountain West States (MWS: Arizona, New Mexico, Nevada, Utah, Colorado, and Wyoming) is illustrated in Fig. 1a, and further emphasized in Fig. 1b. During the summer of 2011 in the MWS region there were over 800 measured DM8HR $\mathrm{O}_{3}$ exceedances above $70 \mathrm{ppb}$ as summarized in Table 1. Even though both model simulations with and without lightning $\mathrm{NO}_{\mathrm{x}}$ underestimated the observed values, the simulation incorporating impacts of lightning $\mathrm{NO}_{x}$ reduced the mean bias across the measurement locations (Fig. 1b) significantly during periods with lightning activity (depicted in Fig. 1c). Significant impacts of lightning $\mathrm{NO}_{x}$ on day to day variations in domain-mean surface DM8HR $\mathrm{O}_{3}$ over the MWS region is also noted in Fig. 1d, which illustrates that lightning $\mathrm{NO}_{\mathrm{x}}$ emissions increase region-average $\mathrm{DM} 8 \mathrm{HR} \mathrm{O}_{3}$ by up to $6 \mathrm{ppb}$ and helps reduce the model low-bias. Recent modeling analysis ${ }^{34}$ in the southeast U.S. has speculated that $\mathrm{NO}_{\mathrm{x}}$ motor vehicle emissions in U.S. National Emission Inventory (NEI) may be overestimated. However, the role of uncertainties associated with other modeled processes as well as the inventory base year used in the analysis, on the magnitude of this overestimation, are not readily apparent (e.g., Simon et al. ${ }^{10}$ ). The MWS region which is the focus of our analysis is a sparsely populated area and consequently anthropogenic emissions in the region are relatively small. Thus, the relative impacts of uncertainties in anthropogenic $\mathrm{NO}_{x}$ on the total $\mathrm{NO}_{\mathrm{x}}$ burden in the region is also comparatively smaller relative to other regions in the U.S. In recent complementary analyses, ${ }^{31}$ we have comprehensively compared model predicted $\mathrm{NO}_{\mathrm{x}}$ mixing ratios with observations for different regions, which also indicated that the model has the best performance over MWS for $\mathrm{NO}_{\mathrm{x}}$ predictions. Thus, the impact of uncertainties in characterizing $\mathrm{NO}_{\mathrm{x}}$ emissions from other sectors on the inferred impacts of lightning $\mathrm{NO}_{\mathrm{x}}$ emissions in the MWS region are expected to be negligible.

To further delineate the impact of lightning activity on daily variations in surface $\mathrm{O}_{3}$, we examined the correlation between lightning activity and the change in model $\mathrm{DM} 8 \mathrm{HR} \mathrm{O}_{3}$ bias (Fig. 1e) (see the Supplementary Information (SI) and Supplementary Fig. 5 for detailed calculation of the lightning flashes; here the grid cell increments of ten are used). The time series of $\mathrm{DM} 8 \mathrm{HR} \mathrm{O}_{3}$ mixing ratios (Fig. 1d) and mean bias difference (Fig. 1e) clearly indicate that the model simulation with lightning $\mathrm{NO}_{\mathrm{x}}$ (NLDN) performed much better episodically in matching the observed values than the simulation without lightning $\mathrm{NO}_{x}$ (Base). Days with highest lightning activity also corresponded to days when the largest improvements in $\mathrm{DM} 8 \mathrm{HR} \mathrm{O}_{3}$ mean bias were realized through the incorporation of lightning $\mathrm{NO}_{x}$ emissions, strongly suggestive of the large role of lightning $\mathrm{NO}_{x}$ emissions in modulating surface-level $\mathrm{O}_{3}$ mixing ratios in this region. The comparison of the daily average mean bias in $\mathrm{DM} 8 \mathrm{HR} \mathrm{O}_{3}$ over the AQS sites in the MWS for both the Base and the NLDN cases presented in Supplementary Fig. 3 further illustrates the improvement in model skill in capturing variations in surface $\mathrm{DM}_{8 \mathrm{HR}} \mathrm{O}_{3}$ in the region due to inclusion of lightning $\mathrm{NO}_{\mathrm{x}}$ emissions.

The relative importance of lightning as a source of reactive nitrogen in the troposphere over the MWS region is further highlighted in Fig. 2 which compares the strength of this source with other sources traditionally considered in estimating $\mathrm{O}_{3}$ in the region. Figure $2 \mathrm{a}-\mathrm{c}$ show the spatial distributions of $\mathrm{NO}_{x}$ emissions from anthropogenic, soil, and lightning sources over the MWS region for July 2011 . Figure $2 d$ presents the relative contributions of these three source categories to daily $\mathrm{NO}_{\mathrm{x}}$ emissions, while Fig. $2 \mathrm{e}$ a. MB (NLDN-Base)

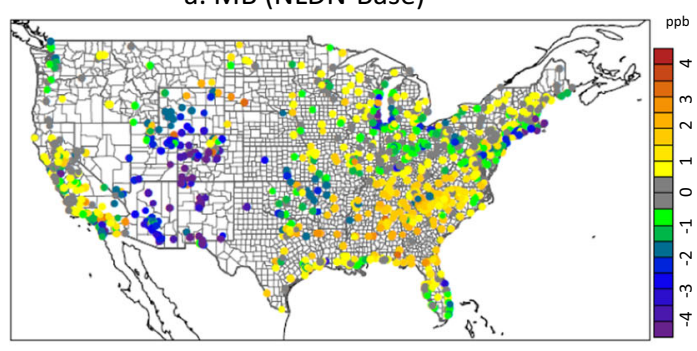

b. MB (NLDN-Base)

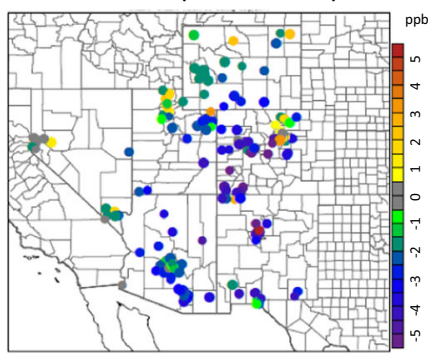

c. Lightning flashes

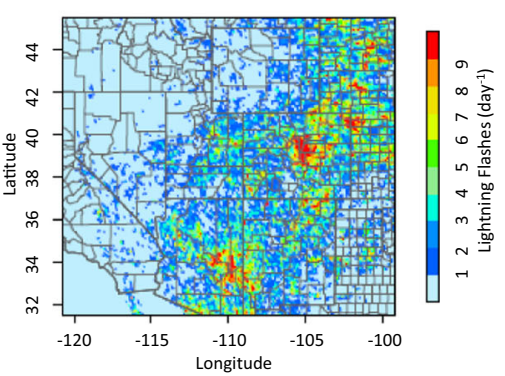

d. DM8HR O3 Over MWS (No. of Sites: 182)

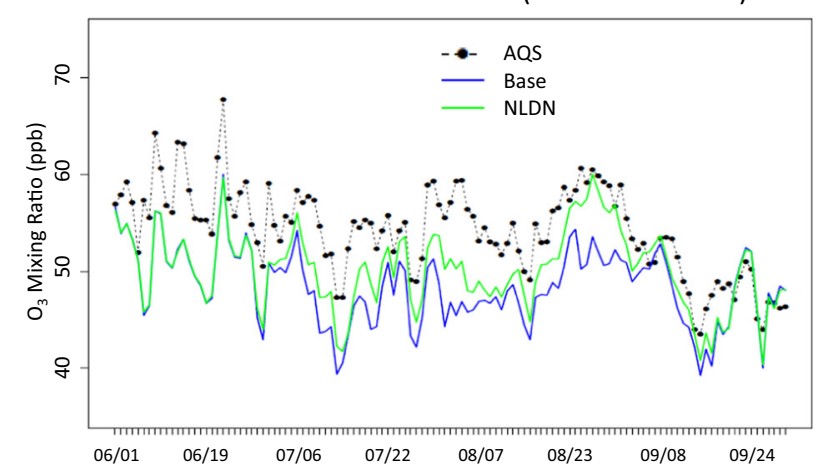

e. Mean Bias Difference and Lightning flashes over MWS

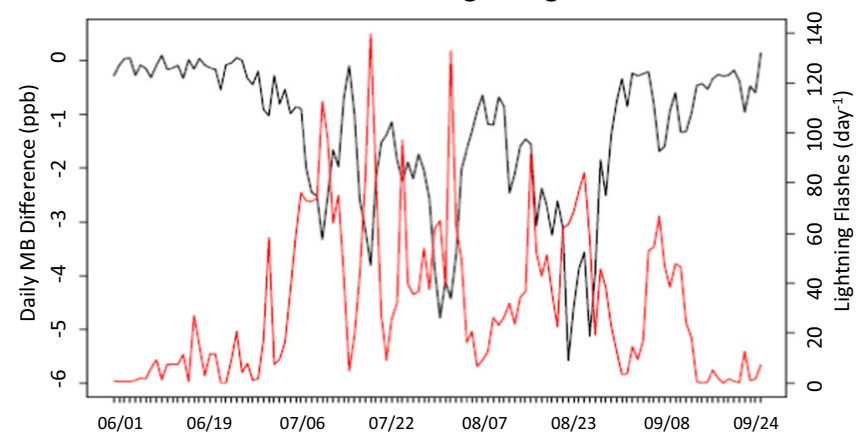

Fig. 1 Impact of lightning events on $\mathrm{O}_{3}$ production during summer 2011. a Mean bias reduction over continental US between simulations with and without lightning $\mathrm{NO}_{\mathrm{x}}$. $\mathbf{b}$ Same as a but focus on the MWS. c The average daily lightning flashes during July 2011 . d Time series of observed and modeled DM8HR $\mathrm{O}_{3}$ mixing ratios. e Time series of the mean bias difference between the two simulations and the daily mean lightning flashes. 
quantifies the daily fraction of total $\mathrm{NO}_{\mathrm{x}}$ emissions that can be attributed to lightning. Note, for Fig. 2d, e, we limit the analysis to portions of the MWS region east of the $115^{\circ} \mathrm{W}$ longitude to minimize the influence of urban centers. As indicated in Fig. 2e, the lightning produced $\mathrm{NO}_{\mathrm{x}}$ constitutes $15-50 \%$ of daily $\mathrm{NO}_{\mathrm{x}}$ emissions in these remote regions and on average $\sim 30 \%$ during July 2011, resulting in the significant impact on surface $\mathrm{O}_{3}$ illustrated earlier. The release of lightning $\mathrm{NO}_{x}$ in such magnitudes into the atmosphere in this region could also potentially modulate atmospheric nitrogen deposition amounts in the region, and further emphasizes the need for air quality models to include lightning $\mathrm{NO}_{\mathrm{x}}$ emissions to accurately simulate both atmospheric chemistry and deposition in the MWS region.

The significant impacts of lightning on air quality in the MWS region are however not unique to the summer of 2011. To leverage observations from the 2014 DISCOVER-AQ (Deriving Information on Surface Conditions from COlumn and VERtically Resolved Observations Relevant to Air Quality) field campaign, as a case study, WRF-CMAQ model simulations with (NLDN) and without (Base) lightning $\mathrm{NO}_{\mathrm{x}}$ emissions were performed for a period encompassing the field study and model results were compared with measurements at the Boulder Atmospheric Observatory (BAO) site. Maximum surface-level $\mathrm{O}_{3}$ mixing ratios

Table 1. Summary of the observed and modeled $\mathrm{DM} \mathrm{HR} \mathrm{O}_{3}$ mixing ratios in MWS.

\begin{tabular}{ll}
\hline Event criteria $(\mathrm{ppb})$ & $\begin{array}{l}\text { Number of occurrences } \\
\text { (site-day) }\end{array}$ \\
\hline MD8HR O $_{3} \geq 70$ (observed) & 803 \\
Simulated difference (NLDN - Base) $\geq 15$ & 12 \\
Simulated difference $\geq 10$ & 288 \\
Simulated difference $\geq 5$ & 2494 \\
Maximum simulated difference: 17 & 1 \\
\hline
\end{tabular}

were observed on July 28th, and the evolution of vertical $\mathrm{O}_{3}$ structure inferred from the lidar measurements during 26-29 July 2014 is shown in Fig. 3a. In these illustrations, the observed lidar $\mathrm{O}_{3}$ profiles are aggregated to the model vertical grid and temporally averaged to hourly values. Figure $3 \mathrm{~b}$ shows the corresponding Base model (without lightning $\mathrm{NO}_{\mathrm{x}}$ ) simulated values and Fig. $3 c$ shows the corresponding simulated values when lightning $\mathrm{NO}_{\mathrm{x}}$ is included. Significant discrepancies are noted between the simulated and observed evolution of vertical $\mathrm{O}_{3}$ distributions on these days, with the model generally underestimating the development of high $\mathrm{O}_{3}$. Also, noted in the observed lidar profiles on most days, is the existence of localized high $\mathrm{O}_{3}$ aloft, suggestive of in situ production rather than intrusion of stratospheric air from higher altitudes. Comparison of Fig. 3a, b, $\mathrm{c}$ indicates that the simulated evolution of vertical $\mathrm{O}_{3}$ distribution and values with lightning $\mathrm{NO}_{\mathrm{x}}$ (Fig. $3 \mathrm{c}$ ) matched the observations more closely than the case without lightning emissions. In general, the Base model shows overestimation on July 26th and underestimation on July 28th and 29th, while the simulation with lightning $\mathrm{NO}_{x}$ improved the predicted $\mathrm{O}_{3}$ values for both these cases, i.e., decreased values on July $26^{\text {th }}$ and increased values on July 28th and 29th. The difference between the two model cases is illustrated in Fig. $3 \mathrm{~d}$. The evolution of peak $\mathrm{O}_{3}$ over this period is further depicted in Fig. $4 \mathrm{a}$, b that compare model and observed vertical profiles of daily maximum $\mathrm{O}_{3}$ mixing ratios for both model cases. From July 26 to 29 , the observed peak values increased by over $20 \mathrm{ppb}$ at the surface (from below $70 \mathrm{ppb}$ to above $90 \mathrm{ppb}$ ), while the simulated values without lightning $\mathrm{NO}_{\mathrm{x}}$ decreased by $10 \mathrm{ppb}$ (from 80 to $70 \mathrm{ppb}$ ); the simulations changed from more than $10 \mathrm{ppb}$ over-prediction on July 26th to more than $20 \mathrm{ppb}$ under-prediction on July 29th. However, when lightning $\mathrm{NO}_{\mathrm{x}}$ is included (Fig. $4 b$ ), the simulated surface daily maximum $\mathrm{O}_{3}$ mixing ratios are much closer to the observed values (compared to the Base case, the simulated $\mathrm{O}_{3}$ values decreased from 87 to $72 \mathrm{ppb}$ on July 26th and increased from 76 to $89 \mathrm{ppb}$ on July 29th, respectively). Lightning flash data for this period (see

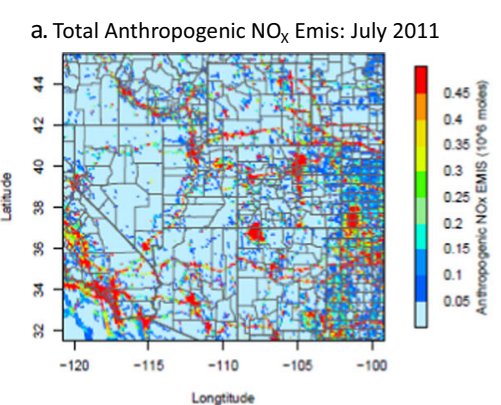

d. Total $\mathrm{NO}_{\mathrm{x}}$ emissions over MWS during July 2011

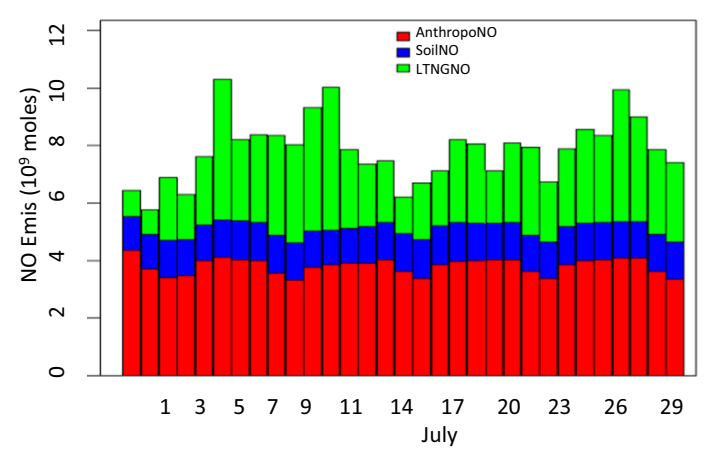

b. Total Soil NO Emis: July 2011

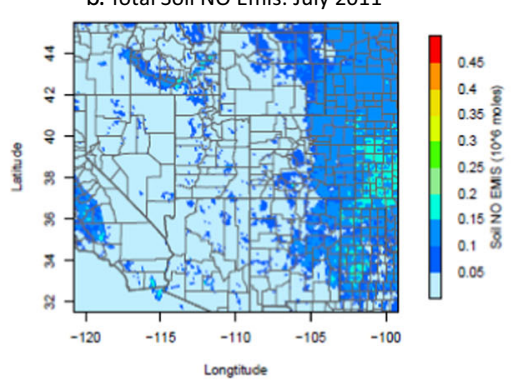

C. Total LTNG NO Emis: July 2011

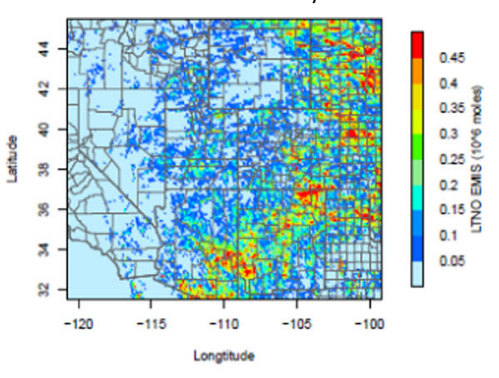

e. LTNG NO to total $\mathrm{NO}_{x}$ emissions over MWS during July 2011

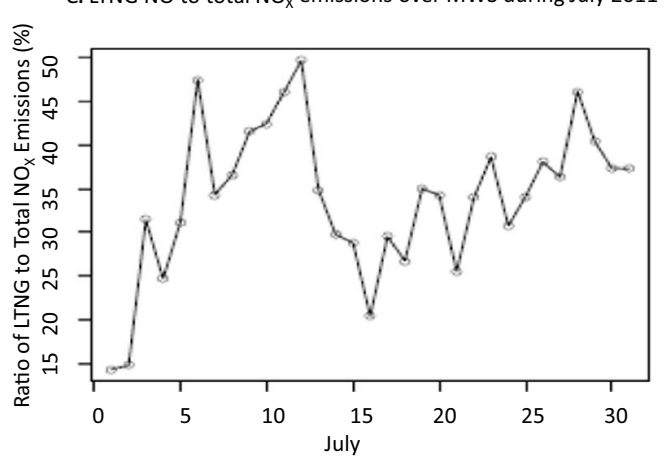

Fig. 2 NO $\mathrm{N}_{\mathrm{x}}$ emissions from different sources in time and space during July, 2011. a Anthropogenic $\mathrm{NO}_{x}$ emissions. b Soil $\mathrm{NO}_{x}$ emissions. $\mathbf{c}$ Lightning $\mathrm{NO}_{x}$ emissions. d Daily total emissions excluding those from the area west of $-115^{\circ}$ longitude. e The daily lightning $\mathrm{NO}_{x}$ ratio to the total $\mathrm{NO}_{\mathrm{x}}$ emissions. 


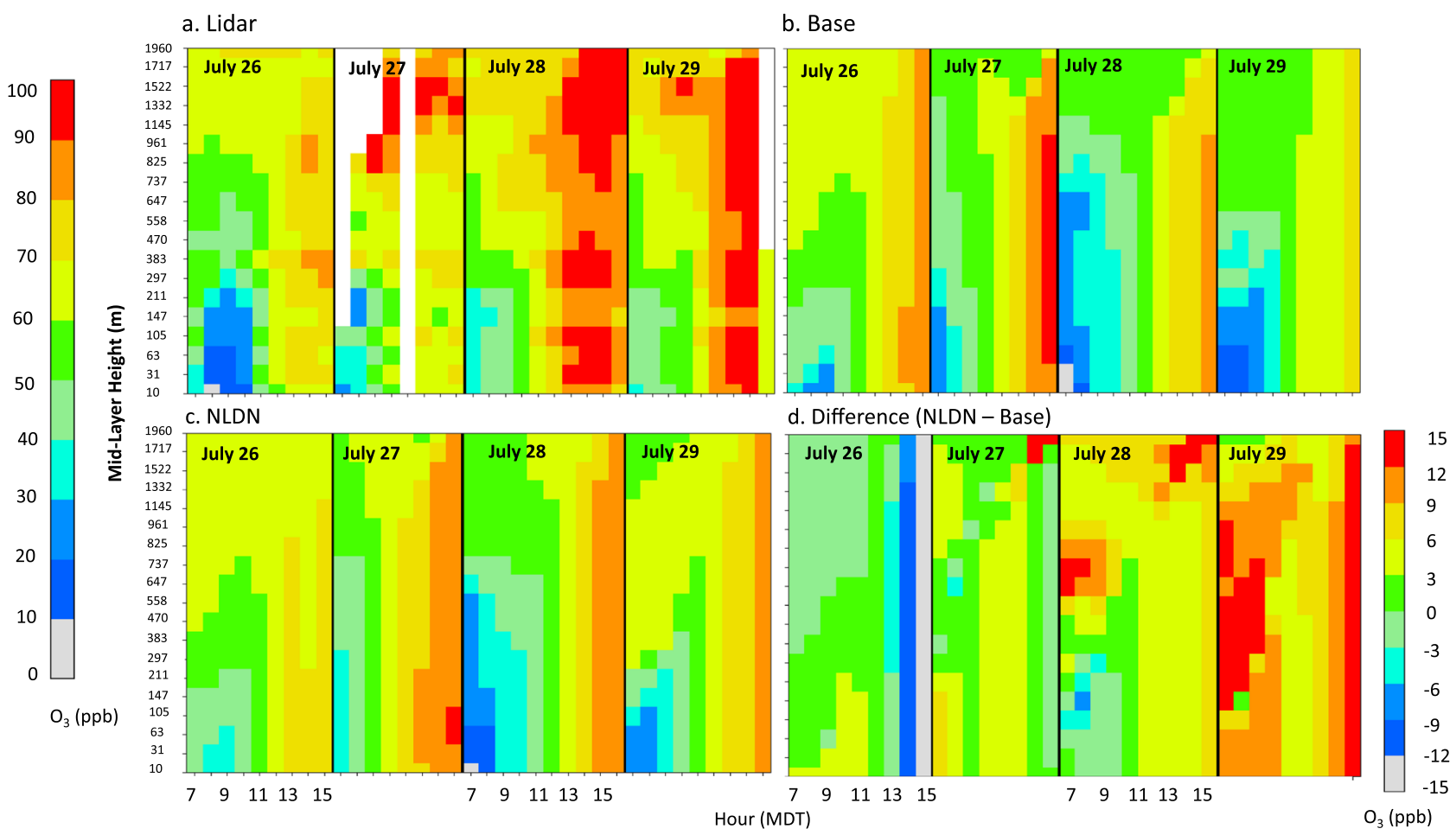

Fig. 3 Lidar measured and simulated $\mathrm{O}_{3}$ mixing ratios at BAO site. a Lidar measurements, $\mathbf{b}$ base simulations, $\mathbf{c}$ simulations with NLDN, d simulation difference (NLDN - Base). The legend on the left is for a-c and the legend at the right bottom is for $\mathbf{d}$.

a. Lidar and Base

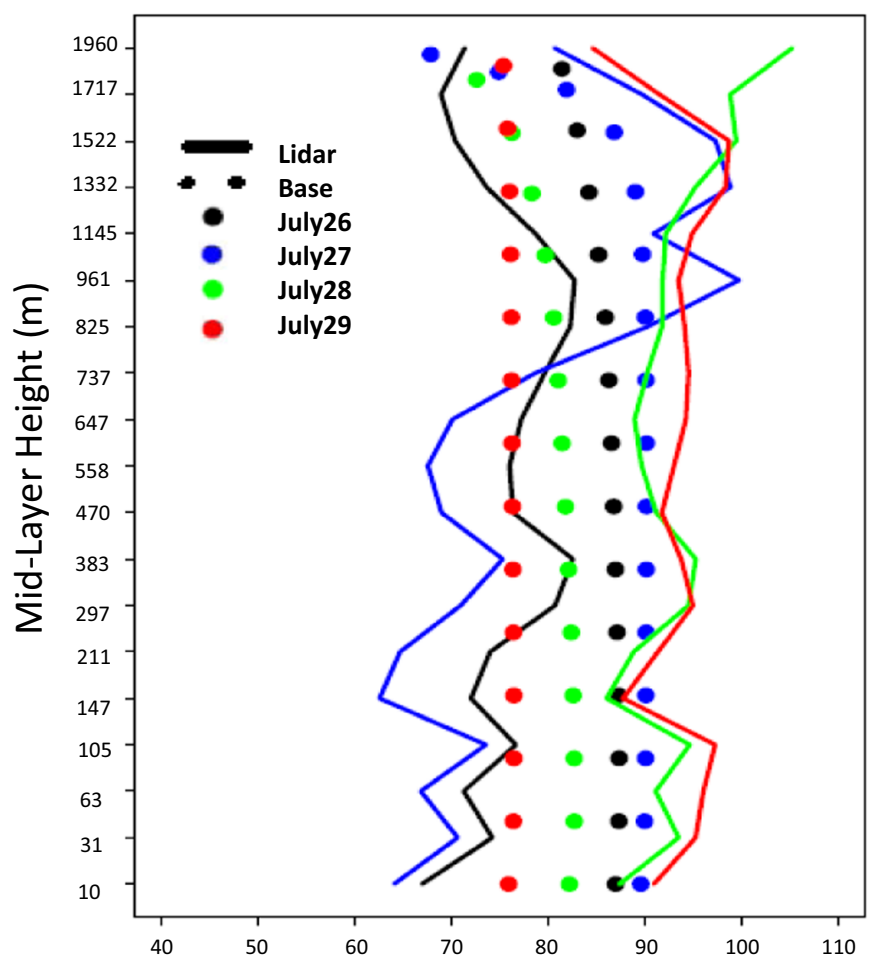

b. Lidar and NLDN

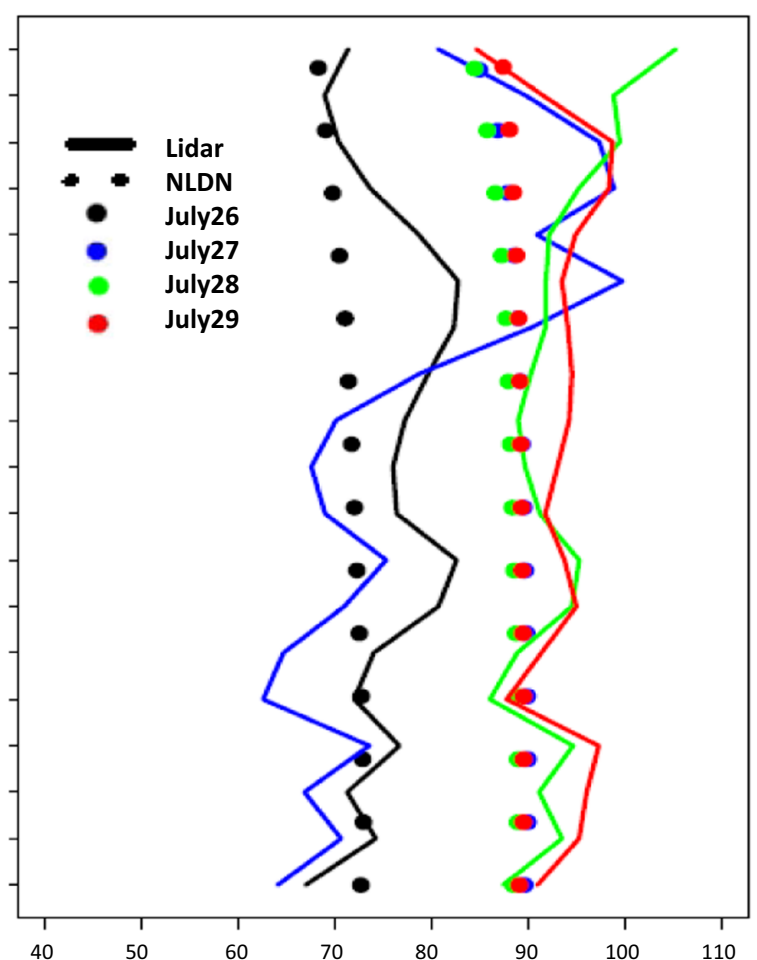

Fig. 4 Lidar measured and simulated $\mathrm{O}_{3}$ mixing ratios at $\mathrm{BAO}$ site. a Maximum $\mathrm{O}_{3}$ mixing ratios across the layers on each day over the episode (Lidar and Base), and $\mathbf{b}$ The same as $\mathbf{a}$, but for Lidar and NLDN. Note that solid lines represent lidar measurements on different days while the circles are the model values. 
Supplementary Fig. 10) indicate periods of active lightning strikes in the region, especially on July 28th and 29th, further suggesting the contribution of lightning $\mathrm{NO}_{x}$ to the observed aloft $\mathrm{O}_{3}$ and subsequent contribution to surface enhancements. These changes in model simulated $\mathrm{O}_{3}$ mixing ratios during this period in response to the injection of lightning $\mathrm{NO}_{\mathrm{x}}$ emissions further indicate the non-linear relationship between $\mathrm{O}_{3}$ and its precursors. Depending on the location and timing of its injection, lightning $\mathrm{NO}_{x}$ emissions can either produce or destroy $\mathrm{O}_{3}$. In proximity of the lightning location, $\mathrm{O}_{3}$ is chemically consumed due to titration by the freshly emitted NO. In contrast, when $\mathrm{NO}_{\mathrm{x}}$ from lightning is transported to locations downwind of the lightning flash, in the presence of sunlight it reacts with VOCs in the surrounding air to produce $\mathrm{O}_{3}$. Note that the uniform distribution of simulated $\mathrm{O}_{3}$ values under about $2 \mathrm{~km}$ shown in Fig. 4 and Supplementary Fig. 11 is due to the fact that maximum $\mathrm{O}_{3}$ values typically occur during early afternoon hours when the planetary boundary layer (PBL) is well mixed.

The importance of lightning $\mathrm{NO}_{\mathrm{x}}$ as a modulator of tropospheric chemistry in the MWS region is further illustrated in Fig. 5 which presents the observed daily mean lightning flashes across the MWS region for the month of July for the years 2011 through 2016 (similar patterns are also observed for August as illustrated in the $\mathrm{SI})$. Figure 6 shows the estimated $\mathrm{NO}_{x}$ emissions released due to these lightning flash rates using the $\mathrm{NO}_{x}$ production algorithm implemented in $\mathrm{CMAQ} .^{30,31}$ Similar intensity of lightning activity occurs every summer (Fig. 5) resulting in comparable amounts of lightning $\mathrm{NO}_{\mathrm{x}}$ emissions released into the atmosphere in the MWS region suggesting that summertime $\mathrm{O}_{3}$ levels in the region could be significantly modulated by this natural source.

\section{DISCUSSION}

With the most up-to-date lightning $\mathrm{NO}_{x}$ production schemes and the vertical distribution algorithm in CMAQ as described and evaluated in recent publications, ${ }^{30,31}$ we examined the importance of lightning $\mathrm{NO}_{x}$ as a modulator of tropospheric chemistry in the U.S. Mountain West States. During summer, lightning $\mathrm{NO}_{x}$ emissions provide a continuous $\mathrm{NO}_{x}$ input to the airshed over the remote MWS region with average monthly contributions to the total $\mathrm{NO}_{x}$ budget of $30 \%$. As a result, significant impact on $\mathrm{O}_{3}$ air quality is both observed and confirmed through analysis of detailed model simulations with and without lightning $\mathrm{NO}_{\mathrm{x}}$ emissions and their detailed comparisons with available routine network and specialized field campaign observations of surface and aloft $\mathrm{O}_{3}$ in the region.

As revealed by the detailed model calculations for summer 2011, lightning $\mathrm{NO}_{\mathrm{x}}$ can contribute up to $21 \mathrm{ppb}$ (or 43\%) of the hourly values of surface-level $\mathrm{O}_{3}$ in the region. Given the comparable level of lightning activity in other years, similar levels of contribution of lightning to surface $\mathrm{O}_{3}$ across the region can be expected. More importantly, as technological advances and regulatory measures reduce anthropogenic $\mathrm{NO}_{\mathrm{x}}$ emissions in the region, the relative contributions of lightning $\mathrm{NO}_{x}$ to $\mathrm{O}_{3}$ levels in the region may increase. Consequently, accurate quantification of lightning $\mathrm{NO}_{x}$ emissions, its contribution to background $\mathrm{O}_{3}$ levels, and its role in modulating air quality in the region will become increasingly important.

\section{METHODS}

CMAQ simulations are performed for the April-September 2011 period over a domain encompassing the contiguous United States and discretized with $12 \mathrm{~km}$ horizontal grid spacing. The Base model configuration and simulation details are the same as those detailed in Kang et al. ${ }^{31}$ with the CB6 chemical mechanism and emissions input data from the 2011 NEl for 2011 simulations. For simulations during the year 2014, the emissions input data are still based on 2011 NEl with 2014 year-specific emissions for EGU (electric generating units), fire, and biogenic sectors from the three states (Colorado, Utah, and Wyoming) constituting the MWS study region. $\mathrm{NO}_{x}$ emissions from electric generating units are based on Continuous Emissions Monitoring and thus are relatively well constrained. The NEI utilizes the MOVES (https://www.epa.gov/moves) modeling system which incorporates detailed information of motor vehicle fleets, miles traveled, fuel information, and the latest emission factors to estimate emissions from this sector. Emissions from wildfires are based on year-specific daily fireactivity from the Hazard Mapping System fire detections and the SMARTFIRE system (http://www.getbluesky.org/smartfire/docs/Raffuse 2007.pdf). The lightning-induced $\mathrm{NO}_{\mathrm{x}}$ is calculated based on the NLDN
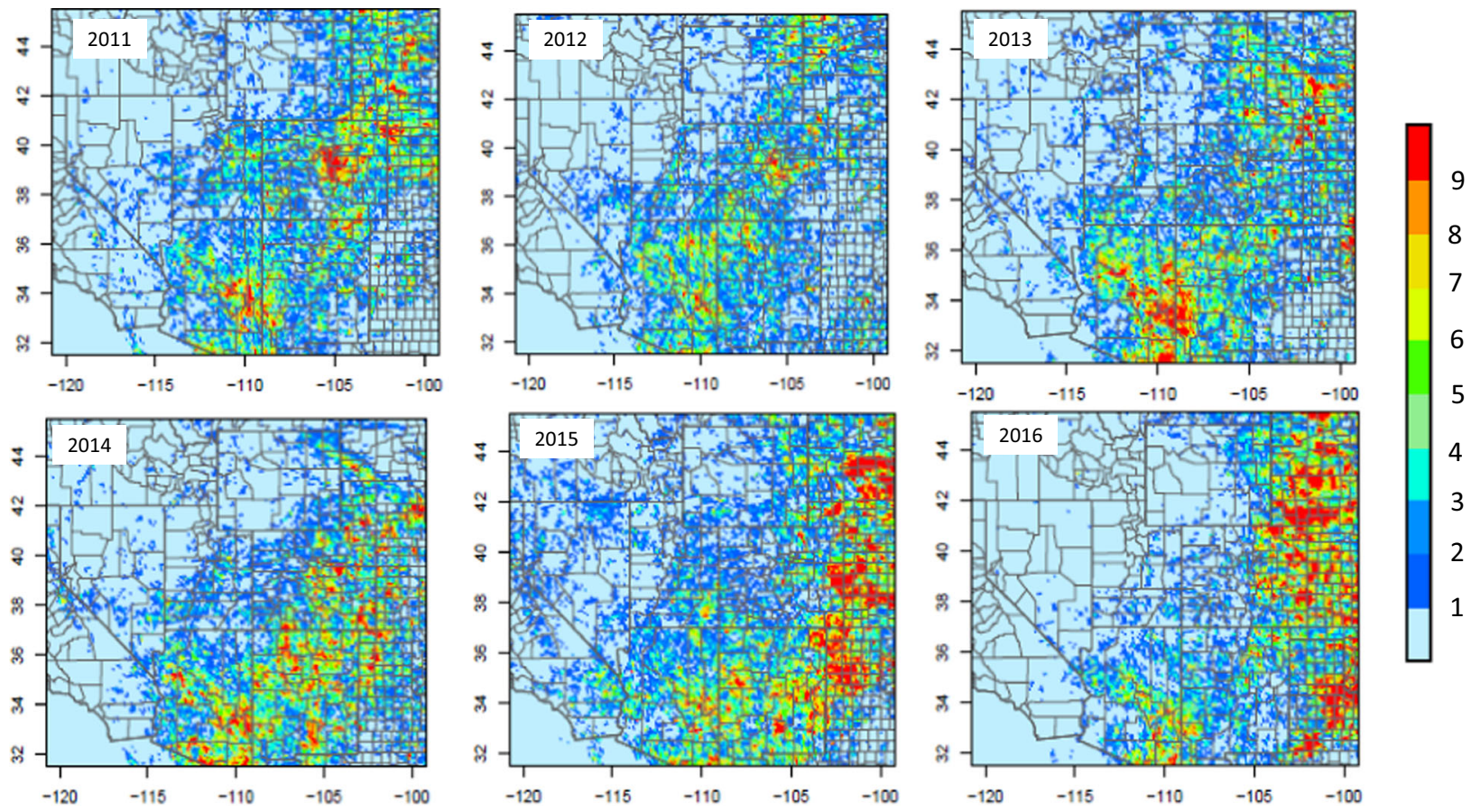

Fig. 5 Daily mean lightning flashes over MWS during July from 2011 to 2016. 

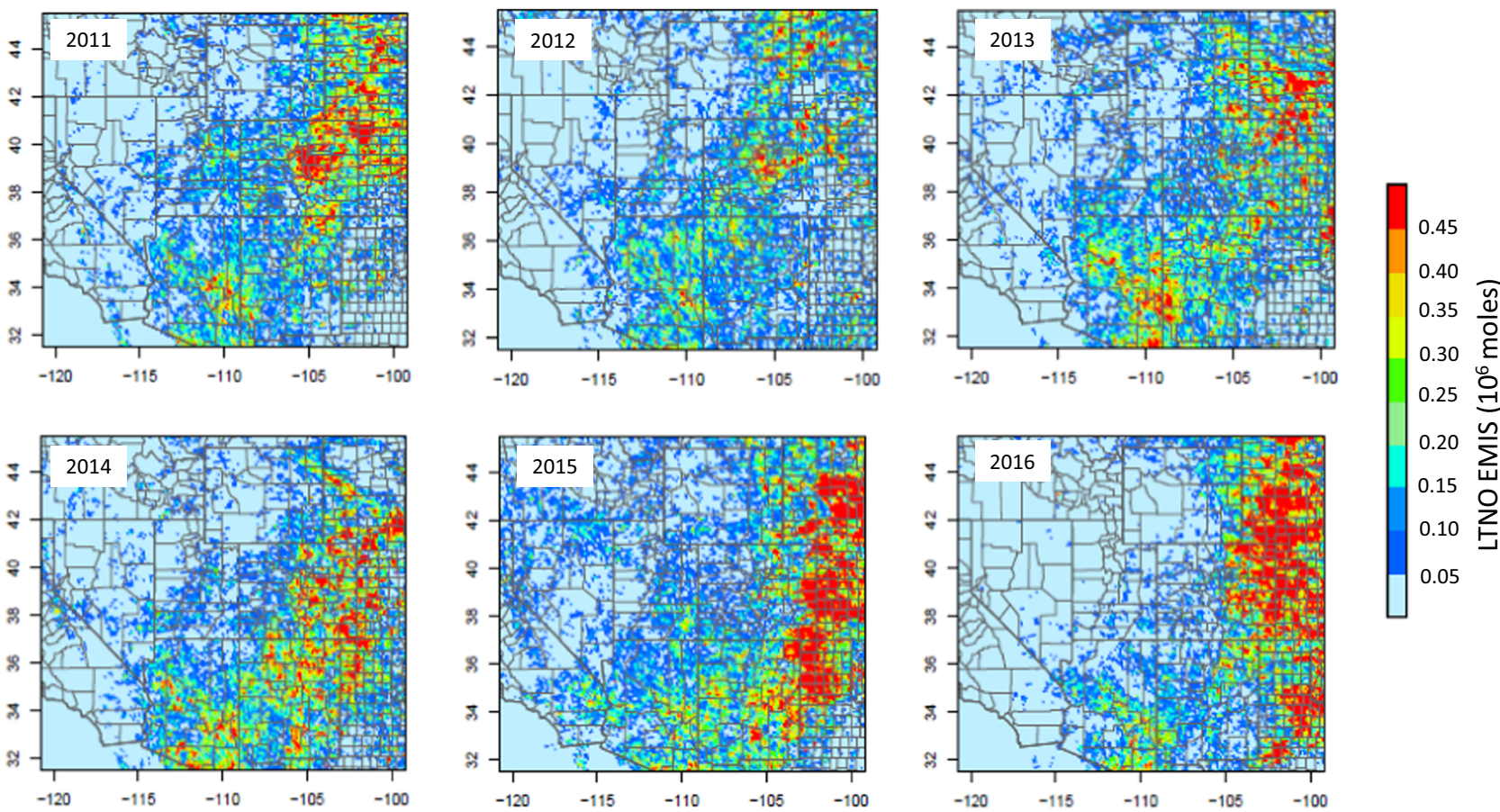

Fig. $6 \mathrm{NO}_{\mathrm{x}}$ emissions from lightning in July from 2011 to 2016 over MWS.

observed cloud-to-ground (CG) lightning flashes that are gridded to the model grid as hourly total flashes, and intra-cloud (IC) flashes based on the climatological IC-to-CG ratio. The vertical distribution of lightning $\mathrm{NO}_{x}$ release follows Kang et al. ${ }^{30}$ The lightning $\mathrm{NO}_{x}$ production rate over landbased grid cells is set to 350 moles/stroke (this value is about the middle of the range suggested by recent studies ${ }^{13}$ that have explicitly reported lightning- $\mathrm{NO}_{x}$ yields using observational constraints). To evaluate the performance of the two model cases for 2011, we compare simulated hourly and $\mathrm{DM} 8 \mathrm{HR} \mathrm{O}_{3}$ mixing ratios with corresponding measured values at sites from the air quality system network. To further examine the impact of lightning $\mathrm{NO}_{x}$ emissions on atmospheric composition and chemistry we conducted model simulations for the period of the 2014 DISCOVER-AQ field campaign in Colorado and analyzed model time-height $\mathrm{O}_{3}$ distributions in conjunction with those inferred from lidar measurements taken by the National Oceanic and Atmospheric Administration's Earth System Research Laboratory ${ }^{35,36}$ at BAO.

\section{DATA AVAILABILITY}

CMAQ model documentation and released versions of the source code, including all model code used in his study, are available at https://www.epa.gov/cmaq. The data processing and analysis scripts are available upon request. The WRF model is available for download through the WRF website (http://www.wrf-model.org/index. php). All data used to create the tables and illustrations in the manuscript are available at https://zenodo.org/record/3246375. Additional input/output data for CMAQ model utilized for this analysis are available through contact with the corresponding author. The lightning flash observation data in their native form are available for purchase from Vaisala Inc. (https://www.vaisala.com/en/products/ systems/lightning-detection).

Received: 22 August 2018; Accepted: 31 December 2019; Published online: 30 January 2020

\section{REFERENCES}

1. Lippmann, M. Health effects of ozone a critical review. JAPCA 39, 672-695 (1989).

2. Arneth, A. et al. Terrestrial biogeochemical feedbacks in the climate system. Nature 3, 525-532 (2010).

3. Lu, X. et al. Severe surface ozone pollution in China: a global perspective. Environ. Sci. Tech. Lett. 5, 487-494 (2018).
4. Sun, L. et al. Impacts of meteorology and emissions on summertime surface ozone increases over central eastern China between 2003 and 2015, atmos. Chem. Phys. 19, 1455-1469 (2019).

5. Ding, A. J., Wang, T., Thouret, V., Cammas, J.-P. \& Nédélec, P. Tropospheric ozone climatology over Beijing: analysis of aircraft data from MOZAIC program. Atmos. Chem. Phys. 8, 1-13 (2008).

6. Haagen-Smit, A. J. Chemistry and physiology of Los Angeles smog. Ind. Eng. Res. 44, 1342-1346 (1952).

7. Cooper, O. R., Langford, O. A., Parrish, D. D. \& Fahey, D. W. Challenges of a lowered U.S. ozone standard. Science 348, 1096-1097 (2015).

8. Zhang, L. et al. Sources contributing to background surface ozone in the US Intermountain West. Atmos. Chem. Phys. 14, 5295-5309 (2014).

9. Jaffe, D. A. \& Ray, J. Increase in surface ozone at rural sites in the western US. Atmos. Environ. 41, 5452-5463 (2007).

10. Simon, H., Reff, A., Wells, B., Xing, J. \& Frank, N. Ozone trends across the United States over a period of decreasing $\mathrm{NO}_{\mathrm{x}}$ and VOC emissions. Environ. Sci. Technol. 49, 186-195 (2015).

11. Cooper, O. R., Gao, R. S., Tarasick, D., Leblanc, T. \& Sweeney, C. Long-term ozone trends at rural ozone monitoring sites across the United States, 1990-2010. J. Geophys. Res. Atmos. https://doi.org/10.1029/2012JD018261 (2012).

12. Parrish, D. D. et al. Long-term changes in lower tropospheric baseline ozone concentrations at northern mid-latitudes. Atmos. Chem. Phys. 12, 11485-11504 (2012).

13. Murray, L. T. Lightning $\mathrm{NO}_{x}$ and impacts on air quality. Curr. Pollut. Rep. https:// doi.org/10.1007/s40726-016-0031-7 (2016).

14. Ott, L. E. et al. Production of lightning $\mathrm{NO}_{x}$ and its vertical distribution calculated from three-dimensional cloud-scale chemical transport model simulations. J. Geophys. Res. https://doi.org/10.1029/2009JD011880 (2010).

15. Labrador, L. J. Strong sensitivity of the global mean $\mathrm{OH}$ concentration and the tropospheric oxidizing efficiency to the source of $\mathrm{NO}_{\mathrm{x}}$ from lightning. Geophys. Res. Lett. 31, L06, 102 (2004)

16. Schumann, U. \& Huntrieser, H. The global lightning-induced nitrogen oxides source. Atmos. Chem. Phys. 7, 3823-3907 (2007).

17. Lamarque, J. F. et al. Historical (1850-2000) gridded anthropogenic and biomass burning emissions of reactive gases and aerosols: methodology and application. Atmos. Chem. Phys. 10, 7017-7093 (2010).

18. Clark, S. K., Ward, D. S. \& Mahowald, N. M. Parameterization-based uncertainty in future lightning flash density. Geophys. Res. Lett. https://doi.org/10.1002/ 2017GL073017 (2017).

19. Luo, C., Wang, Y. \& Koshak, W. J. Development of a self-consistent lightning $\mathrm{NO}_{\mathrm{X}}$ simulation in large-scale 3-D models. J. Geophys. Res. Atmos. https://doi.org/ 10.1002/2016/JD026225 (2017). 
20. Finney, D. L., Doherty, R. M., Wild, O. \& Abrham, N. L. The impact of lightning on tropospheric ozone chemistry using a new global lightning parameterization. Atmos. Chem. Phys. 16, 7507-7522 (2016).

21. Tost, H., Joeckel, P. J. \& Lelieveld, J. Lightning and convection parameterizationsuncertainties in global modeling. Atmos. Chem. Phys. 7, 4553-4568 (2007).

22. Pickering, K. E., Wang, Y., Tao, W. K., Price, C. \& Muller, J. F. Vertical distributions of lightning $\mathrm{NO}_{\mathrm{X}}$ for use in regional and global chemical transport models. J. Geophys. Res. 103, 31204-31216 (1998).

23. Wang, L. et al. Estimating the influence of lightning on upper tropospheric ozone using NLDN lightning data and CMAQ model. Atmos. Environ. 67, 219-228 (2013).

24. Miyazaki, K., Eskes, H. J., Sudo, K. \& Zhang, C. Global lightning NOx production estimated by an assimilation of multiple satellite data sets. Atmos. Chem. Phys. 14, 3277-3305 (2014).

25. Kaynak, B. et al. The effect of lightning $\mathrm{NO}_{x}$ production on surface ozone in the continental United States. Atmos. Chem. Phys. 8, 5151-5159 (2008).

26. Heath, N. K., Pleim, J. E., Gilliam, R. C. \& Kang, D. A simple lightning assimilation technique for improving retrospective WRF simulations. J. Adv. Model. Earth Syst https://doi.org/10.1002/2016MS000735 (2016).

27. Allen, D. J. et al. Impact of lightning-NO on eastern United States photochemistry during the summer of 2006 as determined using the CMAQ model. Atmos. Chem. Phys. 12, 173701758 (2012).

28. Byun, D. W. \& Schere, K. L. Review of the governing equations, computational algorithms, and other components of the models-3 community multiscale air quality (CMAQ) modeling system. Appl. Mech. Rev. 59, 51-77 (2006).

29. Appel, K. W. et al. Description and evaluation of the community multiscale air quality (CMAQ) modeling system version 5.1. Geosci. Model Dev. 10, 1703-1732 (2017).

30. Kang, D. et al. Simulating lightning NOx production in CMAQ: evolution of scientific updates. Geosci. Model Dev. 12, 3071-3083 (2019).

31. Kang, D. et al. Simulating lightning NO production in CMAQv5.2: performance evaluations. Geosci. Model Dev. 12, 4409-4424 (2019).

32. Cummins, K. L. et al. A combined TOA/MDF technology upgrade of the U.S National lightning detection network. J. Geophys. Res. 103, 9035-9044 (1998).

33. Nag, A., Murphy, M. J., Cummins, K. L., Pifer, A. E. \& Cramer, A. Recent evolution of the U.S. National Lightning Detection Network. 23rd International Lightning Detection conference \& 5th International Lightning Meteorology Conference, 18-21 March, Tucson, Arizona (2014).

34. Travis, K. R. et al. Why do models overestimate surface ozone in the Southeast United States? Atmos. Chem. Phys. 16, 13561-13577 (2016).

35. Sullivan, J. T. et al. Lidar observations revealing transport of $\mathrm{O}_{3}$ in the presence of a nocturnal low-level jet: Regional implications for "next-day" pollution. Atmos. Environ. 158, 160-171 (2017).

36. Wang, L. et al. Evaluation of lightning-induced tropospheric ozone enhancements observed by ozone lidar and simulated by WRF/Chem. Atmos. Environ. 115, 185-191 (2015).

\section{ACKNOWLEDGEMENTS}

We thank ESRL/NOAA for making available the ozone lidar measurement. The authors thank Christian Hogrefe, James Kelly, and Thomas Pierce (U.S. EPA) for their constructive comments and suggestions during the internal review process. The views expressed in this paper are those of the authors and do not necessarily represent the views or policies of the U.S. EPA.

\section{AUTHOR CONTRIBUTIONS}

D.K. conceived the study, performed the analysis, and prepared the manuscript. R.M advised on interpreting the results and writing the manuscript. G.P. prepared the emissions data and provided the scripts to interpret the contributions of emission sources. R.G. provided the model scripts and model configurations. D.W. contributed to the model development and model simulations; all co-authors reviewed the manuscript.

\section{COMPETING INTERESTS}

The authors declare no competing interests.

\section{ADDITIONAL INFORMATION}

Supplementary information is available for this paper at https://doi.org/10.1038/ s41612-020-0108-2.

Correspondence and requests for materials should be addressed to D.K.

Reprints and permission information is available at http://www.nature.com/ reprints

Publisher's note Springer Nature remains neutral with regard to jurisdictional claims in published maps and institutional affiliations.

(i) Open Access This article is licensed under a Creative Commons Attribution 4.0 International License, which permits use, sharing, adaptation, distribution and reproduction in any medium or format, as long as you give appropriate credit to the original author(s) and the source, provide a link to the Creative Commons license, and indicate if changes were made. The images or other third party material in this article are included in the article's Creative Commons license, unless indicated otherwise in a credit line to the material. If material is not included in the article's Creative Commons license and your intended use is not permitted by statutory regulation or exceeds the permitted use, you will need to obtain permission directly from the copyright holder. To view a copy of this license, visit http://creativecommons. org/licenses/by/4.0/.

This is a U.S. government work and not under copyright protection in the U.S.; foreign copyright protection may apply 2020 